\title{
1920
}

\section{Was sonst noch geschah}
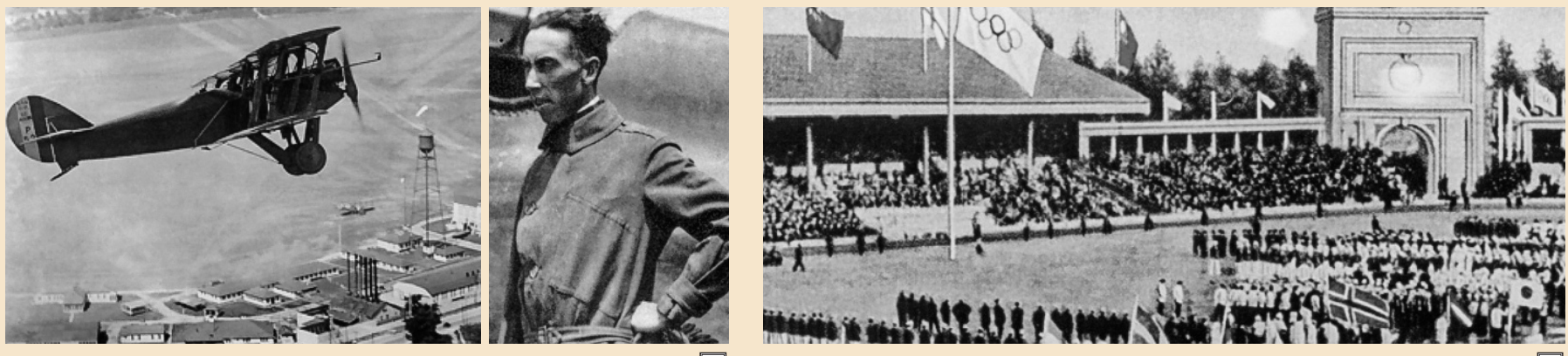

[1]

2
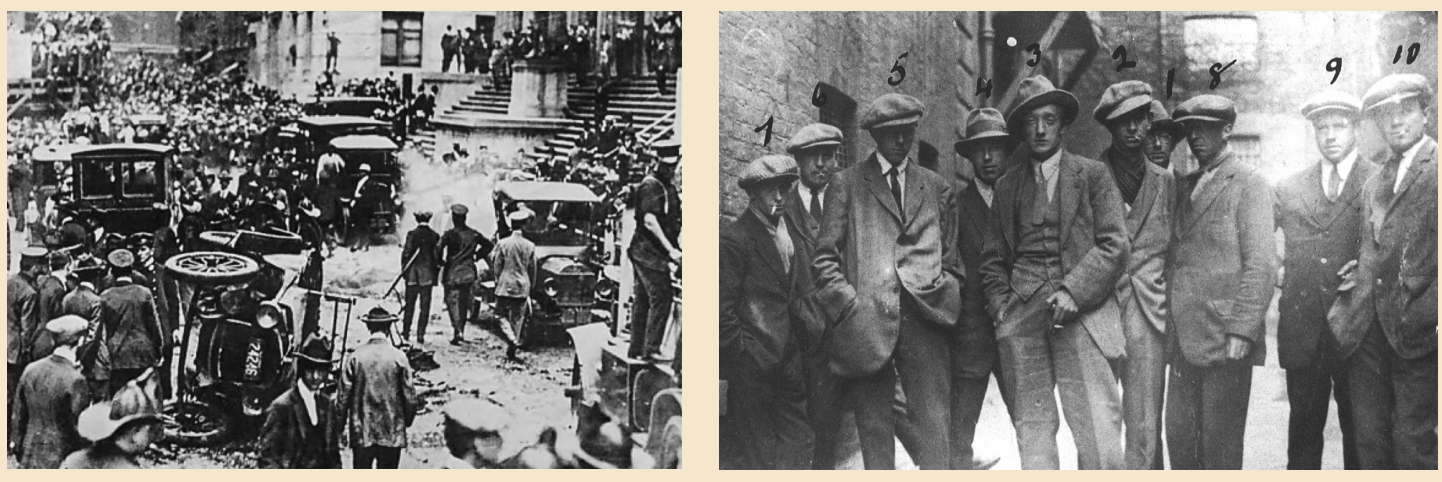

3

4

\section{Januar}

Der Friedensvertrag von Versailles tritt in Kraft.

\section{Februar}

Der US-Amerikaner Major Rudolph William «Shorty» Schroeder erreicht als Erster eine Höhe von über 10000 Metern mit einem Flugzeug.

\section{März}

Griechenland beginnt mit der Nutzung des gregorianischen Kalenders.

\section{April}

Die Olympischen Sommerspiele werden in Antwerpen (Belgien) eröffnet. Die fünf ineinandergreifenden Ringe und die dazugehörige Flagge werden erstmals bei den Spielen verwendet.

\section{Mai}

Papst Benedikt XV. spricht Jeanne d’Arc, die Jungfrau von Orléans, heilig.

\section{Juni}

Ein neuer Grenzvertrag zwischen Deutschland und Dänemark überträgt Nordschleswig an Dänemark.

\section{Juli}

Das Protektorat Britisch-Ostafrika wird in die britische Kronkolonie Kenia umgewandelt.

\section{August}

In den USA entsteht die spätere National Football League (NFL).

\section{September}

Eine Bombe in einem Pferdewagen explodiert vor dem J.-P.-MorganGebäude in der Wall Street, 38 Menschen werden getötet und 400 verletzt.

\section{Oktober}

Italien annektiert auf der Basis des Vertrages von Saint-Germain Südtirol.

\section{$4 \quad$ November}

Bloody Sunday: Die Irisch-Republikanische Armee erschiesst 14 britische Agenten in Dublin (siehe Foto). Später am Tag rächen sich britische Kräfte mit einem Massaker bei einer GaelicFootball-Veranstaltung im Norden der Stadt, 13 Zuschauer und ein Spieler werden getötet sowie 60 weitere Menschen verletzt.

\section{Dezember}

Das Erdbeben von Haiyuan (auch Erdbeben von Gansu genannt) erschüttert mit einer Stärke von 8,6 Ningxia (damals Gansu) in China. 200000 Menschen verlieren ihr Leben. 